\title{
Comparing lacustrine environments: the importance of the kind of habitat on the structure of fishes
}

\author{
Comparando ambientes lacustres: a importância do tipo de habitat na estrutura \\ de peixes
}

Reinaldo José de Castro ${ }^{1 *}$, Raoul Henry ${ }^{2}$, Carla Ferragut ${ }^{3}$ and Mayara Casartelli ${ }^{3}$

${ }^{1}$ Laboratório de Dinâmica de Populaçốes de Peixes, Departamento de Hidrobiologia, Centro de Ciências Biológicas e da Saúde, Universidade Federal de São Carlos - UFSCar, Rodovia Washington Luís, Km 235, SP-310, CEP 13565-905, São Carlos, SP, Brasil

${ }^{2}$ Departamento de Zoologia, Instituto de Biociências, Universidade Estadual Paulista - UNESP, Rua Prof. Dr. Antonio Celso Wagner Zanin, s/n, Distrito de Rubião Júnior, CEP 18618-689, Botucatu, SP, Brasil

${ }^{3}$ Instituto de Botânica, Núcleo de Pesquisas em Ecologia - NPE, Avenida Miguel Stéfano, 3031, Água Funda, CEP 04301-902, São Paulo, SP, Brasil

*e-mail: reinaldocastro@ufscar.br

Cite as: Castro, R.J. et al. Comparing lacustrine environments: the importance of the kind of habitat on the structure of fishes. Acta Limnologica Brasiliensia, 2018, vol. 30, e303.

Abstract: Aim: Fish diversity in two lentic environments: a lake connected (Barbosa lake) to a river and an artificial reservoir (Ninfeias reservoir) were determined in the dry and rainy periods in 2015. We expected to find more diversity in the connected lake and greater abundance in the reservoir. Methods: Specimens were caught using gill nets. Moreover, environmental parameters such as temperature, electrical conductivity, $\mathrm{pH}$, dissolved oxygen and water transparency were measured during the two periods. Results: 546 specimens were collected from 9 families, 12 genera and 15 species of the orders Characiformes, Siluriformes, Cichliformes and Gymnotiformes. Pimelodus maculatus was the most abundant species in the connected lake. Two species were caught from the reservoir: Geophagus brasiliensis and Hoplias malabaricus, the former being predominant. The dominant species in the studied environments corresponded to $48.71 \%$ of the total number of specimens. The ichthyofaunal composition from the lake showed a high richness of the order Characiformes (66.7\%). Siluriformes and Gymnotiformes represented 13.3\% each and the order Cichliformes only $6.7 \%$ of the total number of species. In the artificial reservoir, there was an equivalent contribution of Cichliformes and Characiformes. The diversity was higher in the lake $\left(H^{\prime}=2.05\right)$ and lower in the reservoir $\left(H^{\prime}=0.34\right)$. Significant differences $(\mathrm{p}<0.05)$ of diversity were found between the connected lake and the reservoir. The catch of fish was lower in the dry season $(24.7 \%)$ than the rainy season (62.3\%). The principal component analysis (PCA) showed segregation between the two environments and periods, which was due to the difference in water electrical conductivity. The prevalence of species of the orders Characiformes and Siluriformes follows the pattern found for the ichthyofauna in the Neotropical region. Conclusions: The analysis of distinct patterns of diversity and abundance of the ichthyofauna from the studied environments showed that the environment connected to the river has a high diversity when compared to the reservoir. The presence of aquatic macrophytes of different species may be a regulating factor in structuring the fish community of the lake connected to the river.

Keywords: fish; abundance; connected lagoon; shallow reservoir; assemblage structure. 
Resumo: Objetivo: A diversidade de peixes em dois ambientes lacustres, uma lagoa conectada (lagoa do Barbosa) ao rio e outro artificial (reservatório das Ninfeias) foram determinadas nos períodos seco e chuvoso de 2015. Métodos: Espécimes foram capturados utilizando-se redes de emalhar. Parâmetros ambientais como a temperatura, condutividade elétrica, $\mathrm{pH}$, oxigênio dissolvido e transparência da água foram medidos durante os dois períodos. Resultados: Foram coletados 546 exemplares de peixes, de 9 famílias, 12 gêneros e 15 espécies das ordens Characiformes, Siluriformes, Cichliformes e Gymnotiformes. Pimelodus maculatus foi a espécie mais abundante na lagoa do Barbosa. No reservatório foram capturadas duas espécies, Geophagus brasiliensis e Hoplias malabaricus, com predomínio da primeira. As espécies dominantes nos ambientes estudados corresponderam a $48,71 \%$ do total de exemplares. A composiçáo da ictiofauna da lagoa revelou uma maior riqueza da ordem Characiformes (66,7\%). Siluriformes e Gymnotiformes representaram 13,3\% cada e a ordem Cichliformes 6,7\% do total de espécies. No reservatório artificial houve contribuição equivalente de Cichliformes e de Characiformes. A diversidade foi maior na lagoa $\left(H^{\prime}=2,05\right)$ e menor no reservatório $\left(H^{\prime}=0,34\right)$. Diferenças significativas $(\mathrm{p}<0,05)$ da diversidade foram encontradas entre a lagoa conectada e o reservatório. A captura de peixes foi menor na seca $(24,7 \%)$ que no período chuvoso $(75,3 \%)$. A PCA separou os dois ambientes e os períodos pela diferença na condutividade elétrica da água. A prevalência de espécies das ordens Characiformes e Siluriformes obedece ao padráo encontrado para a ictiofauna da regiáo Neotropical. Conclusóes: A análise do padrão de diversidade da ictiofauna dos ambientes estudados mostrou que o ambiente conectado ao rio apresenta maior diversidade quando comparado ao reservatório artificial. A presença de macrófitas aquáticas de diferentes espécies pode ser um fator regulador na estruturaçáo da comunidade de peixes da lagoa conectada ao rio.

Palavras-chave: peixe; abundância; lagoa conectada; reservatório raso; estrutura da assembleia.

\section{Introduction}

Oxbow lakes, located close to large rivers, usually support a complex trophic structure, having a wide variety of niches, habitats and food sources for their fish assemblages (Carvalho et al., 2005), consisting mainly of small species and larger sized juvenile fish associated with littoral macrophytes (Carvalho et al., 2003).

The fish communities that inhabit lacustrine ecosystems associated to rivers are seasonally dependent on water levels (Luz et al., 2009). Fish assemblage structures can vary drastically even between adjacent biotopes (Petry et al., 2003) and are subject to changes in the physical and chemical conditions of the environment that alter when the hydrological level decreases or increases (Luz et al., 2009).

Lentic environments are essential for maintaining fish fauna and for replenishing fish stocks as they serve as natural nurseries, help replace and conserve local and regional ichthyofauna (Meschiatti et al., 2000). The number of species in oxbow lake-river systems is dependent on changes in physical factors and flood pulses that significantly alter the habitat structure (Junk et al., 1989).

Aspects of fish assemblages in Brazilian lakes were carried out by Baginski et al. (2007) who reported greater stability in fish assemblages in the vegetated littoral zone. Meschiatti et al. (2000) established a direct relationship of small fish, typical of lentic environments, with aquatic macrophytes in Lake Diogo and Infernão. Marçal-Simabuku
\& Peret (2002) related a high feeding activity in species of fish studied in the Beija-flor Dam to aquatic macrophytes. Petry et al. (2003) showed the narrow relationship between fish assemblies and the connectivity between oxbow lakes and rivers.

Agostinho et al. (2007b) reported that the presence of the aquatic macrophyte Eichhornia azurea is of great importance for conserving fish diversity in the Paraná River floodplain. A direct relationship of high diversity of aquatic macrophytes with the richness of fish species was also observed by Agostinho et al. (2003). According to Thomaz \& Cunha (2010), aquatic macrophytes are important in structuring habitats and highly determinant in the composition of associated fauna, including small fish assemblages.

In a study on oxbow lakes in the Paranapanema River, Carvalho et al. (1998) attributed significant importance to the aquatic macrophyte community in the development of habitats for reproduction, shelter, feeding and initial growth of small species such as Cheirodon stenodon and medium-sized migratory species, such as Pimelodus maculatus. Aquatic macrophytes and connectivity play an important role in structuring communities in aquatic environments (Thomaz \& Cunha, 2010; Petry et al., 2003). These plants provide physical structure, increase habitat complexity and spatial heterogeneity (Thomaz \& Cunha, 2010). Carvalho et al. (2005) also recorded a larger number of small individuals near the aquatic macrophytes in an isolated lake (Cavalos Lake). Three oxbow lakes in the Paranapanema River showed 
equivalence in the composition and abundance of fish, however differences in richness and abundance were observed between littoral and open areas (Carvalho et al., 2003).

The connectivity between the river and the lateral lakes apparently contributes to habitat homogeneity and similarity between biotic communities (César \& Henry, 2017). This condition enabled us to examine here the role of connectivity in two different lakes, one marginal to a river, and another an isolated artificial lake, upon the Ichthyofauna. Our hypothesis is that the Barbosa lake (the connected lake) has high species richness and abundance when compared to the Ninfeias reservoir (an artificial reservoir) characterized by high macrophyte coverage, an alternation from clear to turbid waters during the year and a low variation on the abiotic variables due to its small size.

Therefore, in this study we (i) evaluated the ecological attributes (richness, diversity and biomass) and the structure (composition and abundance) of the fish assemblage in two lentic environments: an environment connected to a river and an artificial lake (a shallow reservoir); and (ii) studied the temporal variations on fish richness and abundance withcorrelations with abiotic variables of the water in the two environments.

\section{Material and Methods}

\subsection{Study area}

The selected environments were the Barbosa lake and Ninfeias reservoir (Figure 1). The first one, the Barbosa lake (2330'13.11'S and 48 37'45.17”O), associated with the Paranapanema River, has an elongated and slightly branched shape (maximum length: $1,420 \mathrm{~m}$, maximum width: $550 \mathrm{~m}$, surface area: 203,000 $\mathrm{m}^{2}$, perimeter: $6270 \mathrm{~m}$ ) (Silva \& Henry, 2013,). This lake is largely colonized by marginal aquatic vegetation that forms a belt of Echinochloa polystachya and floating (Eichhornia azurea and Salvinia auriculata) and rooted (Myriophyllum aquaticum) macrophytes (Silva \& Henry, 2013). The Paranapanema river mouth, in the Jurumirim reservoir, is a longitudinal transition zone where oxbow lakes permanently connected or isolated from the river, can be observed (Henry, 2014).

The second environment, the Ninfeias reservoir, is a small artificial ecosystem shaped in 1930 by the damming of the Pirarungaua stream. It is located inside the Fontes do Ipiranga State Park (PEFI in Portuguese) $\left(23^{\circ} 38^{\prime}\right.$ and $23^{\circ} 40^{\prime} \mathrm{S}, 46^{\circ} 36^{\prime}$ and $46^{\circ} 38^{\prime}$ W) within the São Paulo urban network (Bicudo et al., 2002). The PEFI is in the catchment area of Alto Tietê where the springs of the Ipiranga river are located. This shallow and oligo-mesotrophic reservoir has an area of $5,433 \mathrm{~m}^{2}$, a maximum depth of $3.6 \mathrm{~m}$ and mean of $1.32 \mathrm{~m}$ and residence time of 7.2 days (Bicudo et al., 2002). The reservoir presents great abundance of aquatic macrophytes (Bicudo et al., 2002) in its coastal region, and the rooted macrophyte Nymphaea spp. is dominant, however in summer it presents co-abundance with the free-floating macrophyte Utricularia foliosa $\mathrm{L}$ (Pellegrini \& Ferragut, 2012).

\subsection{Sampling}

The fish samples were obtained monthly in two periods established as dry (in April, May and June) and rainy (in October, November and December) in
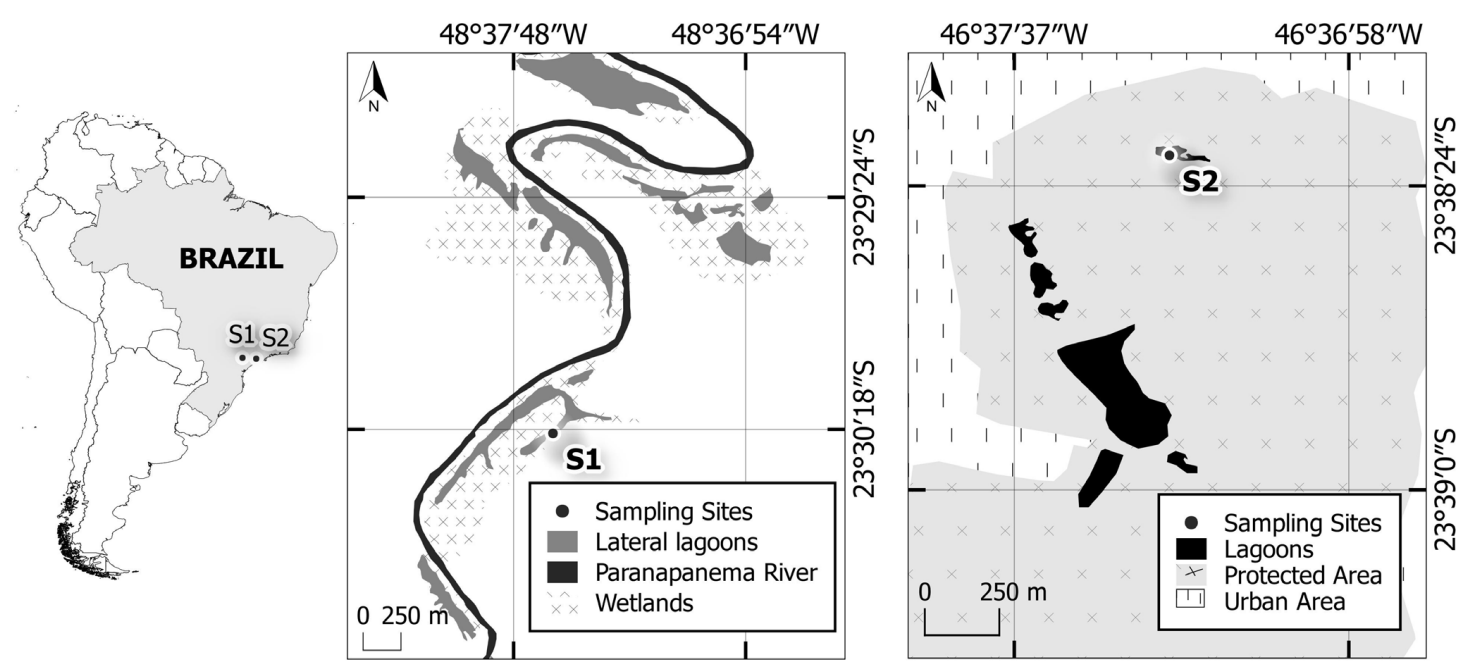

Figure 1. Map showing the location of the Barbosa lake (S1), upper Paranapanema river, Angatuba (SP) and Ninfeias reservoir (S2), Fontes de Ipiranga State Park (PEFI), São Paulo (SP). 
2015 (Figure 2) in the two lacustrine environments totaling six samples at each site.

The samplings were carried out according to standards, using two bundles of gill nets of 3,4 and $5 \mathrm{~cm}$ mesh netting between adjacent knots, each net measuring 20 meters in length, making a total of 60 linear meters in each bundle. The purpose of the two bundles of nets parallel to the macrophyte stands was to verify if there was a relationship between the fish communities with plants found in the two lacustrine environments. The nets were exposed in a 24 hour cycle and the fish were captured every 6 hours.

The caught fish were fixed in 10\% formalin solution for three to 7 days and later preserved in $70 \%$ alcohol for identification. The fish were identified according to the specialized literature (Eschmeyer \& Fong, 2018) and were confirmed by Claudio de Oliveira at the São Paulo State University (UNESP) in Botucatu.

For each specimen collected, the standard length (SL) and total length (TL) expressed in centimeters were measured and the total weight (in grams) was recorded. The material is deposited in the Collection at the Biology and Fish Genetics Laboratory (LBP) at the Department of Morphology at the Institute of Biosciences (IBB) at the São Paulo State University (UNESP) in Botucatu and their respective vouchers are presented in Table 1.

Water samples were collected for dissolved oxygen analysis (DO, Winkler method), $\mathrm{pH}$, electrical conductivity (EC) and suspended matter
(SM) (APHA, 2005). The water transparency was determined using the Secchi disk.

\subsection{Data analysis}

For each sample, the diversity was determined by the Shannon-Wiener index $(H)$ using the number of individuals according to formula $H^{\prime}=-\sum P i . \operatorname{Ln} P i$, where $P i$ is the ratio between the number of specimens of species $i$ and the total number of individuals caught (Ricklefs \& Relyea, 2016) and Simpson's index (D) according to expression $D=\sum p i^{2}$ where $P i$ is the ratio between the number of specimens of species $i$ and the total number of individuals caught (Magurran, 2004).

Pielou's evenness ( $J$, uniformity) of the species distribution was determined by Equation $J=H^{\prime} / \operatorname{Ln} S$, where $S$ is the species richness of the sample (Magurran, 2004).

The constancy of occurrence $(\mathrm{C})$ of the species was determined using the relation between the number of samples containing the species (p) and the total number of samples collected $(\mathrm{P})$, expressed as a percentage by $\mathrm{C}=\mathrm{p} \times 100 / \mathrm{P}$. The species was considered resident (or constant) if $\mathrm{C} \geq 50 \%$, accessory if $25 \% \leq \mathrm{C}>50 \%$ or accidental if $\mathrm{C}<25 \%$ (Dajoz, 1972).

We used a t-test for independent samples to evaluate spatial differences between biotopes relative to the Shannon diversity index.

The Student t-test (Zar, 2010) was used to check for significant differences between biotopes

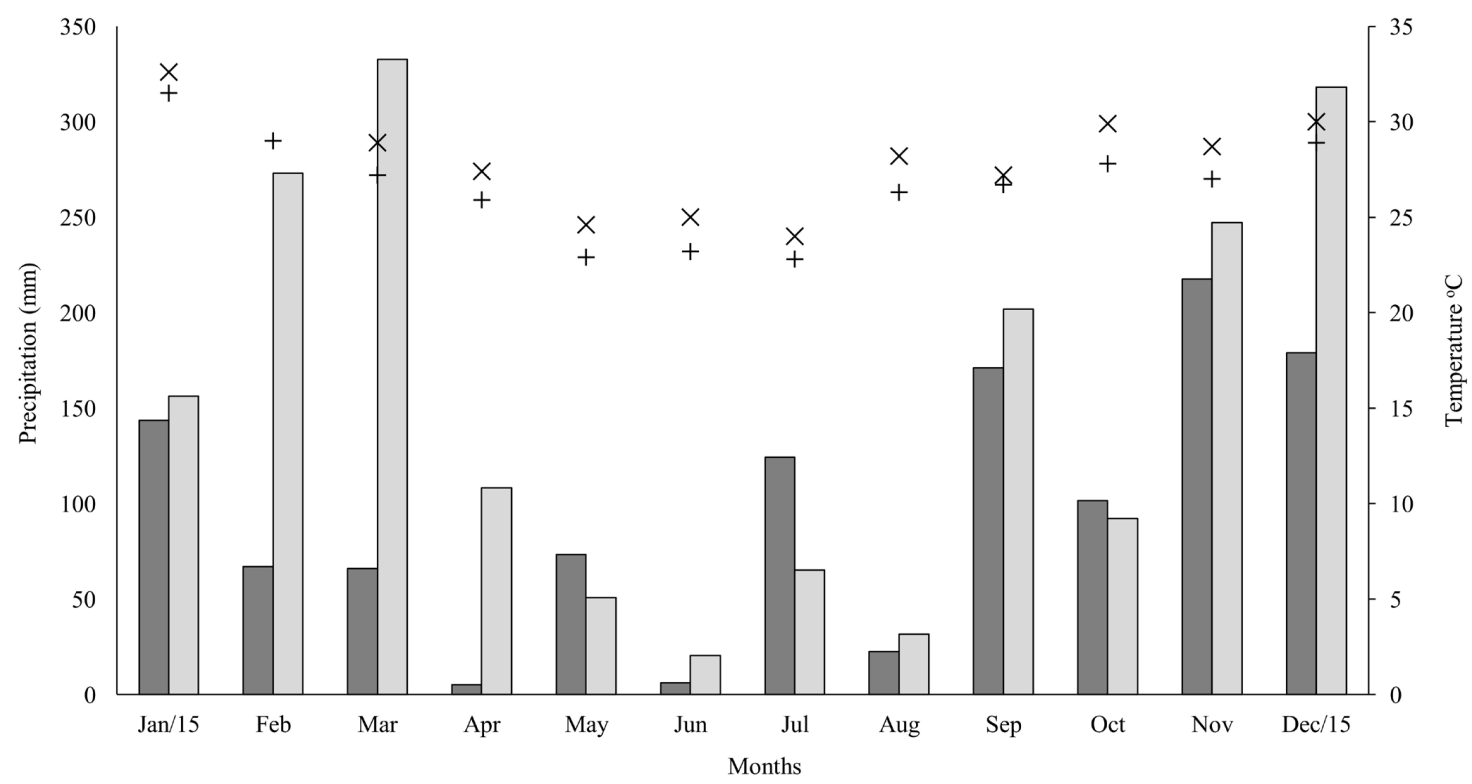

Figure 2. Total monthly precipitation and temperature at Barbosa lake (precipitation, black bars and temperature X) and Ninfeias reservoir (precipitation gray bars and temperature +) in 2015 (From: Inmet, 2018). 


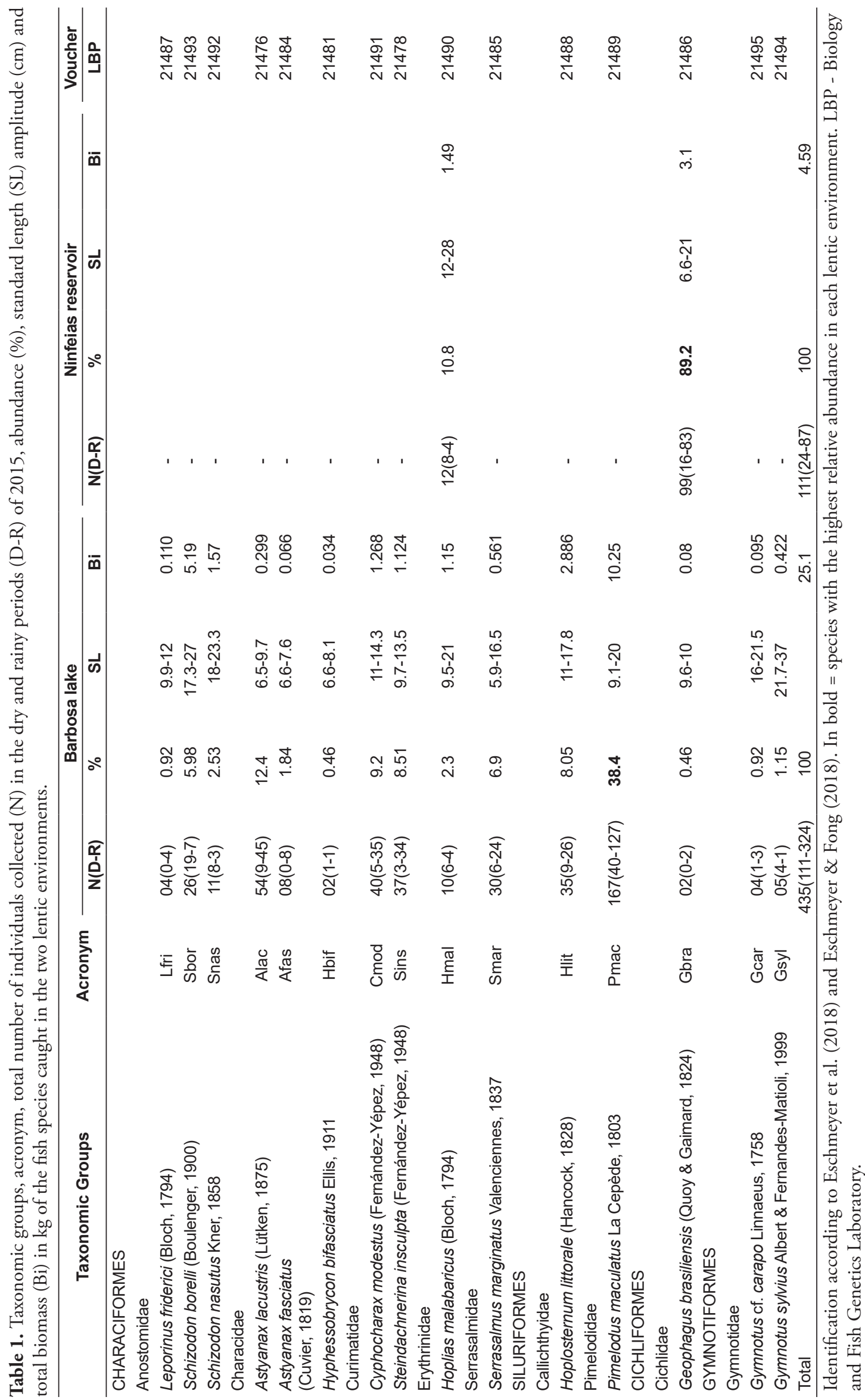


(lake and artificial reservoir) relative to the Shannon diversity index at a significance level of $\mathrm{p}<0.05$.

The temporal influence of abiotic variables on both environments was examined using the principal component analysis (PCA) based on data transformed by logarithms with a covariance matrix using the PC-ORD statistical program (Version 6.0; McCune \& Mefford, 2006).

Multivariate statistics (Correspondence canonical analysis - CCA) were employed, using XLSTAT 3.1 computer software, in order to verify the possible influence of abiotic variables on the abundance and distribution of fish species (Legendre \& Legendre, 2012). For the CCA analysis, the data concerning the individual numbers of species were $\log (x+1)$ transformed and the abiotic data were standardized. In order to determine possible seasonal patterns from CCA and to examine the temporal variations occurred in the lacustrine environments, data from dry (April, May, and June) and rainy seasons (October, November, December) were grouped.

\section{Results}

A total of 546 specimens of the orders Characiformes, Siluriformes, Cichliformes and Gymnotiformes belonging to 9 families (Anostomidae, Characidae, Curimatidae, Erythrinidae, Serrasalmidae, Callichthyidae, Pimelodidae, Cichlidae and Gymnotidae), 12 genera and 15 species were caught in the two sampling sites during the study period (Table 1). The largest species richness (10) was represented by the order Characiformes, followed by Siluriformes and Gymnotiformes with two species each. Only one species (Geophagus brasiliensis) was obtained as representative of the order Cichliformes (Table 1).

In the Barbosa lake, 435 specimens of fish were caught of the orders Characiformes, Siluriformes, Cichliformes and Gymnotiformes, from 9 families (Anostomidae, Characidae, Curimatidae, Erythrinidae, Serrasalmidae, Callichthyidae, Pimelodidae, Cichlidae and Gymnotidae), from 12 genera and 15 species (Table 1). Pimelodidae and Curimatidae were the most abundant families in the Barbosa lake, with 38.4 and $17.7 \%$ of the total, respectively (Table 1 ). The yellow-mandi, Pimelodus maculatus (167 individuals collected) was the most abundant species in this lake, followed by A. altiparanae (12.4\%). The G. brasiliensis species was the least representative, with only 2 specimens caught (Table 1).
In the Ninfeias reservoir, there was a predominance of $G$. brasiliensis, making a total of 99 individuals collected, compared to twelve specimens of Hoplias malabaricus. The two dominant species (P. maculatus and G. brasiliensis) in the lacustrine environments corresponded to $48.7 \%$ of the total number caught in this study (Table 1).

The ichthyofauna of the Barbosa lake presented 10 species belonging to the order Characiformes, corresponding to $66.7 \%$ of the total species caught. Two species were found of the orders Siluriformes and Gymnotiformes and each represented 13.3\% of the total. Moreover, Cichliformes corresponded to only $6.7 \%$ of the total species. In the Ninfeias reservoir, two species $(S=2)$ were recorded: one from the order Cichliformes and the other from Characiformes (Figure 3).

The annual abundance (the values of the dry and rainy periods together) was higher in the connected lake (Barbosa lake) than in the reservoir (Ninfeias reservoir) (Figure 4). Comparing the two annual periods, the abundance in the connected lake was higher in the rainy season $(59.5 \%)$ and lower in the dry season (20.1\%). In the reservoir abundance was similar, corresponding to $8.2 \%$ in the dry period and $12.1 \%$ in the rainy season (Figure 4 ).

The connected lake to the Paranapanema River and the artificial reservoir presented distinct values of diversity and evenness (Table 2). Considering the annual period, the greatest diversity $\left(H^{\prime}=2.05\right)$ was recorded in the Barbosa lake. However, when the indices were determined separately by periods, the highest values of diversity were observed in the dry period in the Barbosa lake and Ninfeias reservoir, and the lowest values were obtained during the rainy season in the two studied environments.

Significant differences in the Shannon diversity were found for the connected lake and reservoir. However, comparing the dry and rainy periods in the sites, there was no difference in the diversity between the periods (Table 2).

The mean and standard deviation of the water temperature, $\mathrm{pH}$, dissolved oxygen, electrical conductivity, suspended matter and water transparency values in the two annual periods are presented in Table 3. In general, the water from the Ninfeias reservoir was more oxygenated during the dry period, slightly more acidic and with a higher electrical conductivity than the Barbosa lake in the two studied periods (Table 3).

The Principal Component Analysis (PCA) of the abiotic water data summarized $72.6 \%$ of the total variability of the data in the first two axes (Figure 5). 
PCA axis 1 separated the studied environments by the marked difference of electrical conductivity, with higher values in the Ninfeias reservoir. In axis 2 of the PCA, the variation of temperature and dissolved oxygen was important in determining the differences between dry and rainy periods. In the rainy season, the two study sites showed higher values of temperature and lower levels of dissolved oxygen in the water. In contrast, in the dry period, the values of dissolved oxygen were higher and the

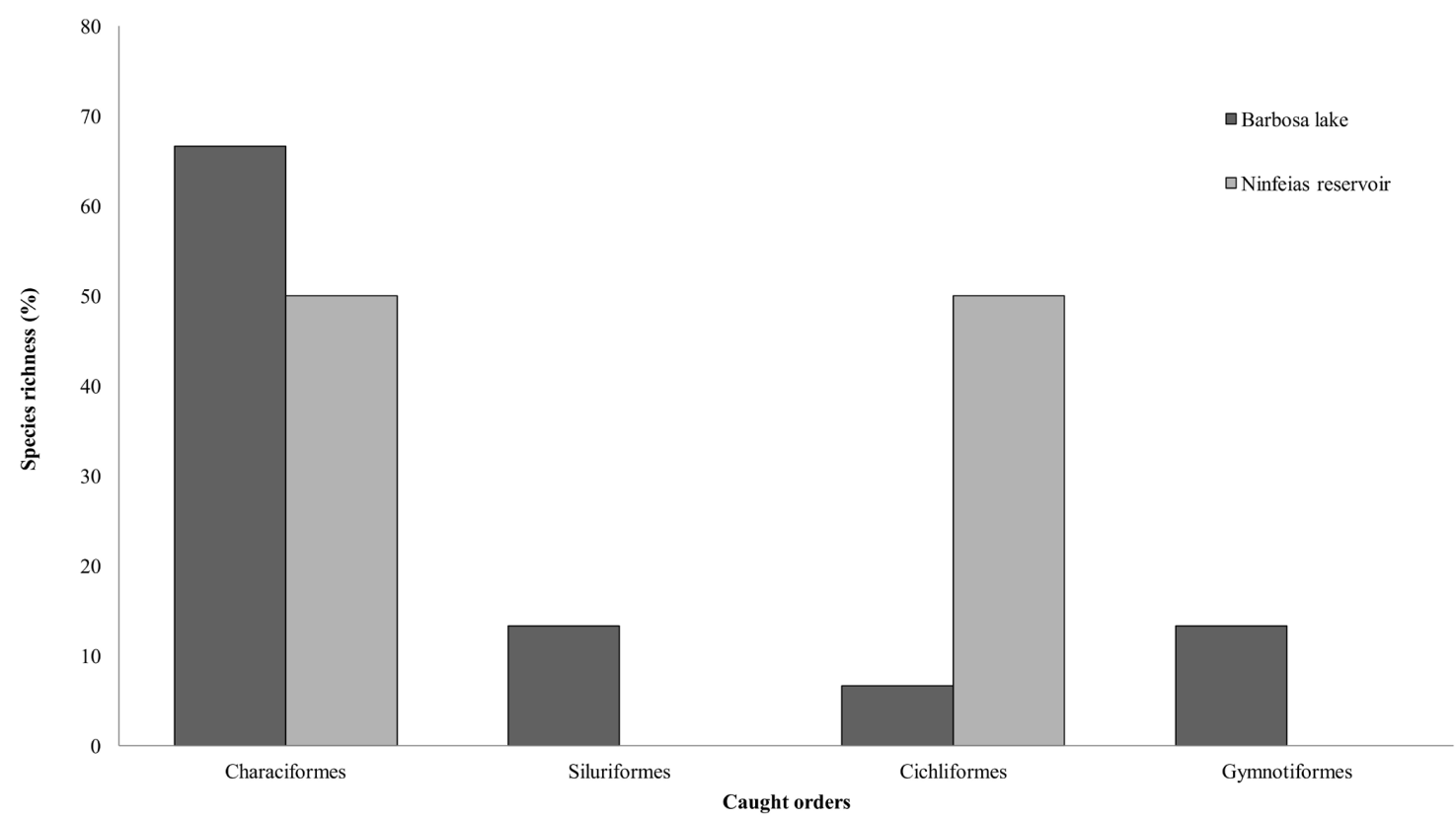

Figure 3. Relative species richness per order caught in the Barbosa lake and Ninfeias reservoir from April to December, 2015.

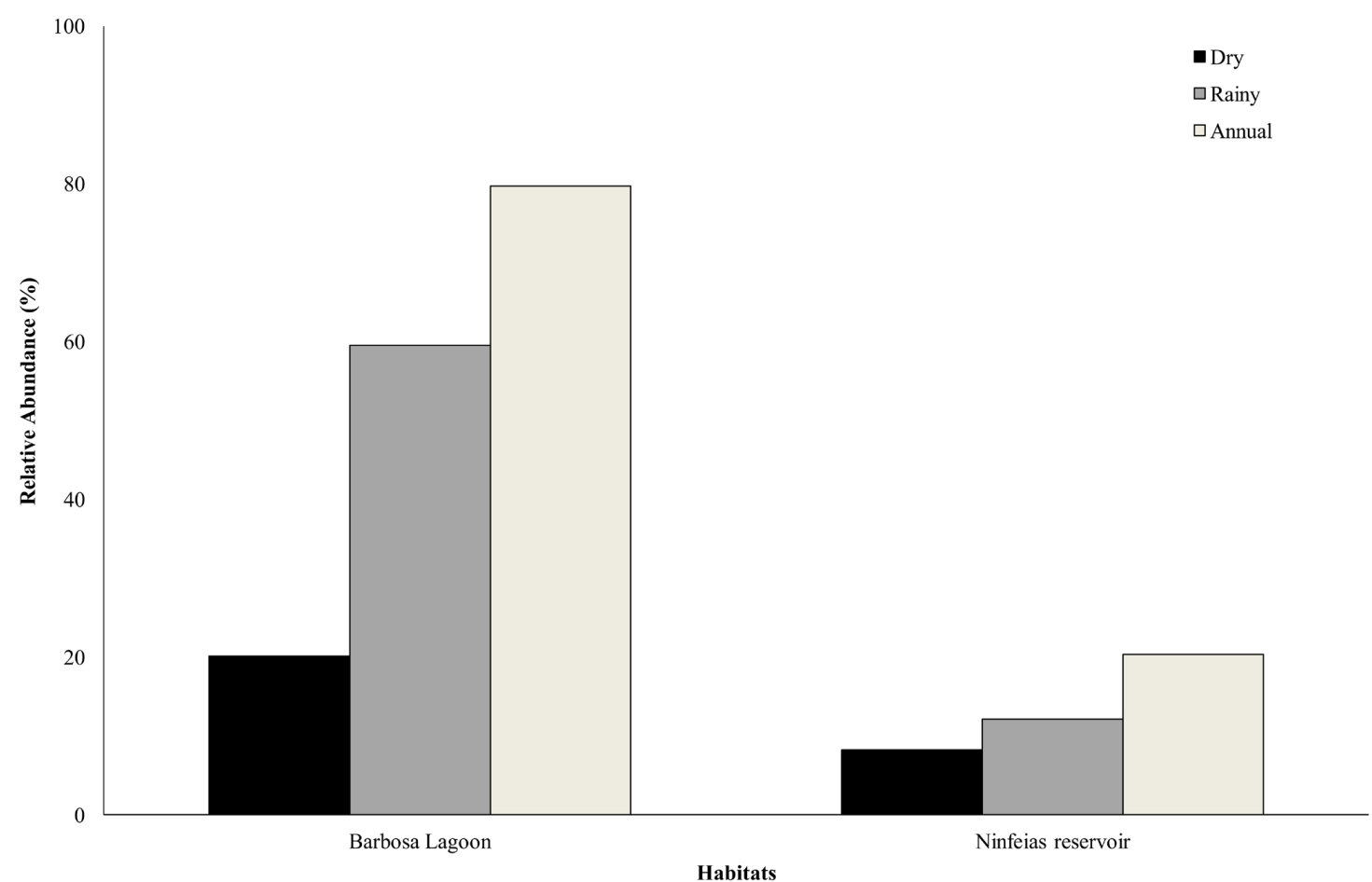

Figure 4. Relative abundance of fish per period (dry, rainy and accumulated) from the Barbosa lake and Ninfeias reservoir. 
water temperature was lower at both sampling sites throughout our study (Figure 5).

The catch constancy analysis revealed that eight species were constant, six accessories and one accidental in Barbosa lake throughout the study period. In the Ninfeias reservoir, the caught species were classified as constant because presence was above $83 \%$ (Table 4).

The CCA summarized the spatial trends in environmental variations and species abundance

Table 2. Shannon (H') diversity index, Pielou's evenness ( $)$, Simpson's index (D), Abundance (A) and Biomass (Bi) in $\mathrm{kg}$ of fish samples caught in the two environments under annual study and in the dry and rainy periods.

\begin{tabular}{|c|c|c|c|c|c|c|c|c|c|c|}
\hline \multirow{2}{*}{ Period } & \multicolumn{5}{|c|}{ Barbosa lake } & \multicolumn{5}{|c|}{ Ninfeias reservoir } \\
\hline & $H^{\prime}$ & $J$ & D & $A(\%)$ & $\mathrm{Bi}$ & $H^{\prime}$ & $J$ & D & $A(\%)$ & $\mathrm{Bi}$ \\
\hline Annual & *2.05 & 0.76 & 0.193 & 100 & 25.1 & ${ }^{*} 0.34$ & 0.49 & 0.805 & 100 & 4.59 \\
\hline Dry & 2.02 & 0.81 & 0.183 & 25.3 & 9.33 & 0.47 & 0.68 & 0.701 & 40.5 & 1.39 \\
\hline Rainy & 1.95 & 0.72 & 0.206 & 74.7 & 15.7 & 0.23 & 0.33 & 0.884 & 59.5 & 3.20 \\
\hline
\end{tabular}

*Significant difference between the sites $(\alpha=0.05$ and critical $\mathrm{t}=1.96)$.

Table 3. Mean and standard deviation (SD) of the physical and chemical variables of water recorded in Barbosa lake and Ninfeias reservoir.

\begin{tabular}{|c|c|c|c|c|}
\hline \multirow[b]{2}{*}{ Abiotic variables } & \multicolumn{2}{|c|}{ Barbosa lake } & \multicolumn{2}{|c|}{ Ninfeias reservoir } \\
\hline & $\begin{array}{c}\text { Mean(士SD) } \\
\text { Dry }\end{array}$ & $\begin{array}{c}\text { Mean( }( \pm S D) \\
\text { Rainy }\end{array}$ & $\begin{array}{c}\text { Mean( }( \pm S D) \\
\text { Dry }\end{array}$ & $\begin{array}{c}\text { Mean }( \pm S D) \\
\text { Rainy }\end{array}$ \\
\hline Water Temperature $\left({ }^{\circ} \mathrm{C}\right)$ & $23.6( \pm 1.26)$ & $25.7( \pm 1.3)$ & $22.8( \pm 0.06)$ & $26.7( \pm 1.61)$ \\
\hline $\mathrm{pH}$ & $6.7( \pm 0.37)$ & $7.5( \pm 0.30)$ & $6.36( \pm 0.12)$ & $6.43( \pm 0.12)$ \\
\hline Dissolved Oxygen (mg L-1) & $4.98( \pm 1.16)$ & $4.63( \pm 0.37)$ & $6.16( \pm 0.30)$ & $4.38( \pm 1.53)$ \\
\hline Electrical conductivity $\left(\mu \mathrm{Scm}^{-1}\right)$ & $34.8( \pm 1.62)$ & $34.4( \pm 4.18)$ & $50.6( \pm 0.67)$ & $57.27( \pm 3.77)$ \\
\hline Suspended matter $\left(\mathrm{mg} \mathrm{L}^{-1}\right)$ & $19.35( \pm 20.46)$ & $9.69( \pm 16.58)$ & $3.33( \pm 1.09)$ & $2.94( \pm 1.02)$ \\
\hline Water transparency $(\mathrm{m})$ & $0.82(0.09)$ & $1.48( \pm 0.70)$ & $1.41(0.45)$ & $1.15( \pm 0.34)$ \\
\hline
\end{tabular}

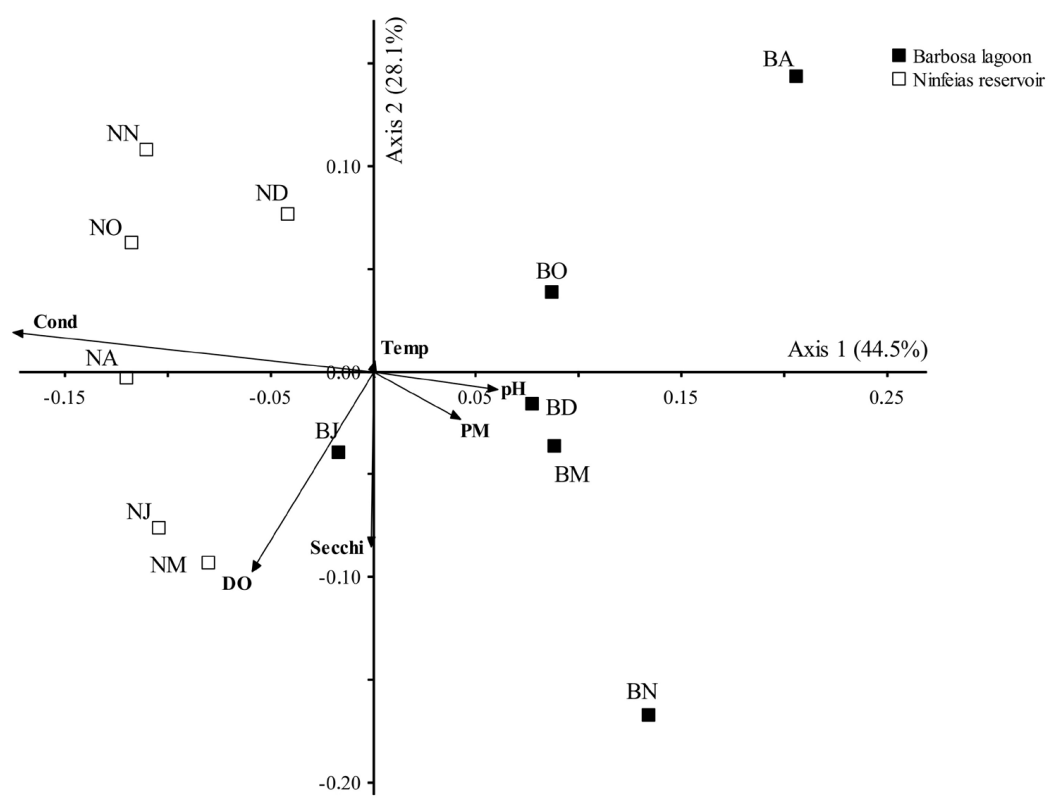

Figure 5. Principal Component Analysis (PCA) involving the abiotic water variables from the Barbosa lake and Ninfeias reservoir in the studied period. Scores abbreviations: BA = Barbosa lake April; BM = Barbosa lake May; $\mathrm{BJ}=$ Barbosa lake June; $\mathrm{BO}=$ Barbosa lake October; $\mathrm{BN}=$ Barbosa lake November and $\mathrm{BD}=\mathrm{Barbosa}$ lake December; $\mathrm{NA}=$ Ninfeias reservoir April; NM = Ninfeias reservoir May; NJ = Ninfeias reservoir June; NO = Ninfeias reservoir October; NN = Ninfeias reservoir November and ND = Ninfeias reservoir December. Vectors: DO = Dissolved Oxygen; $\mathrm{PM}=$ Particulate matter; $\mathrm{pH}=\mathrm{pH}$; Secchi = Transparency; Temp = Water temperature; Cond = Electrical conductivity. 
(Figure 6). The CCA ordination plot shows relationships among fish species with the environmental variables of the sites, Barbosa lake and Ninfeias reservoir, and physical and chemical factors of the water. CCA explained $80.12 \%$ of the total variability of the abundance data. The variable electrical conductivity in the water had a more important role in the formation of axis 1 and, presented high values in the Ninfeias reservoir and low in Barbosa lake. CCA, applied to fish abundance of the Ninfeias reservoir, revealed no seasonal pattern on fish distribution with abiotic variables in the water. However, in the Barbosa lake, a seasonal pattern can be observed on the second

Table 4. Catch Constancy Index in percentage (\%) and the respective classification of fish species caught in the Barbosa lake and Ninfeias reservoir from April to December, 2015.

\begin{tabular}{|c|c|c|c|c|}
\hline \multirow{2}{*}{ Species } & \multicolumn{2}{|c|}{ Barbosa lake } & \multicolumn{2}{|c|}{ Ninfeias reservoir } \\
\hline & $\%$ & Classification & $\%$ & Classification \\
\hline Astyanax lacustris & 100.0 & Constant & & \\
\hline Astyanax fasciatus & 50.0 & Accessory & & \\
\hline Cyphocharax modestus & 66.7 & Constant & & \\
\hline Geophagus brasiliensis & 16.7 & Accidental & 100.0 & Constant \\
\hline Gymnotus sylvius & 33.3 & Accessory & & \\
\hline Gymnotus cf. carapo & 50.0 & Accessory & & \\
\hline Hoplias malabaricus & 100.0 & Constant & 83.3 & Constant \\
\hline Hoplosternum littorale & 100.0 & Constant & & \\
\hline Hyphessobrycon bifasciatus & 33.3 & Accessory & & \\
\hline Leporinus friderici & 33.3 & Accessory & & \\
\hline Pimelodus maculatus & 100.0 & Constant & & \\
\hline Schizodon borelli & 83.3 & Constant & & \\
\hline Schizodon nasutus & 50.0 & Accessory & & \\
\hline Serrasalmus marginatus & 100.0 & Constant & & \\
\hline Steindachnerina insculpta & 83.3 & Constant & & \\
\hline
\end{tabular}

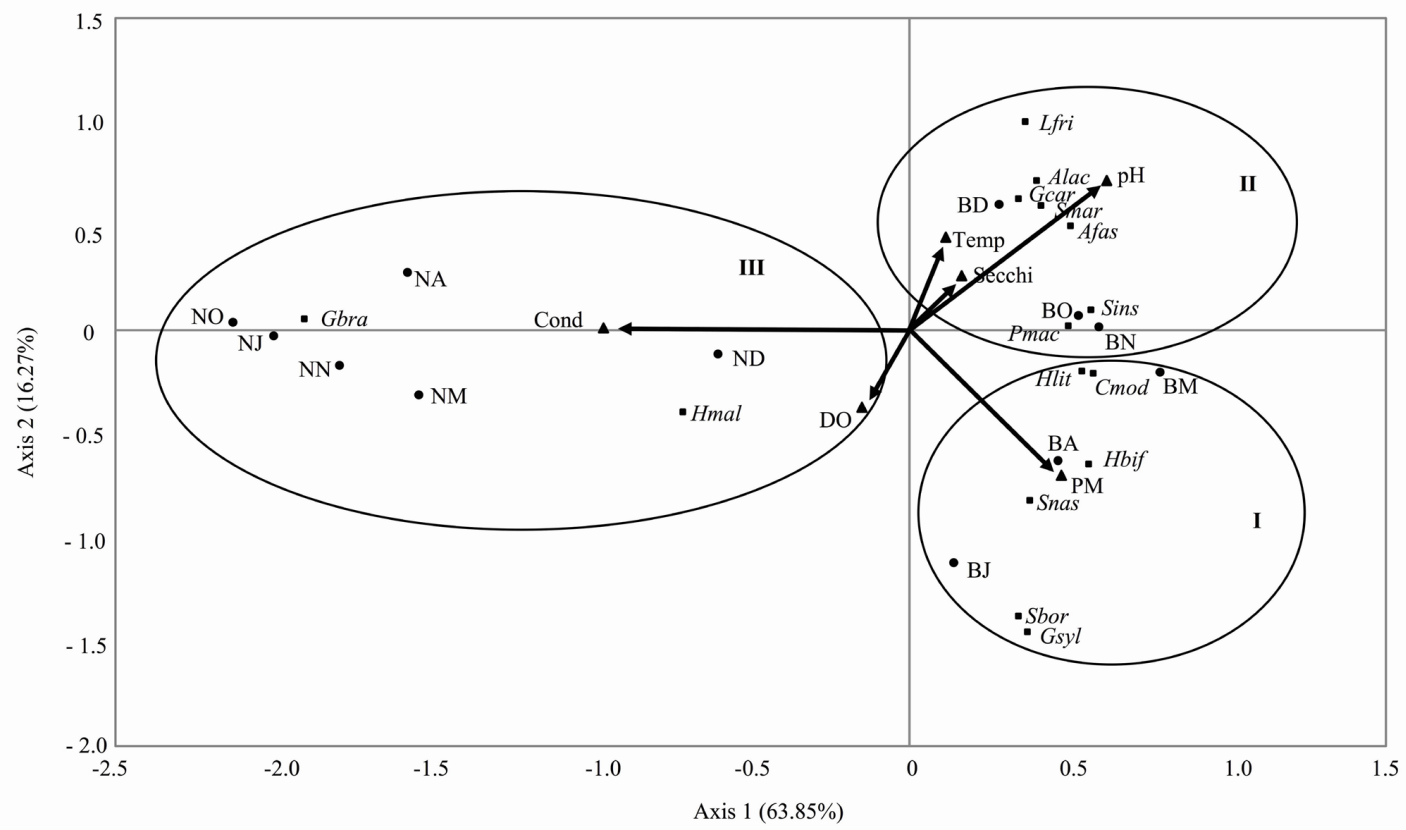

Figure 6. Correspondence canonical analysis (CCA) for the abundance of fishes and the abiotic water variables from the Barbosa lake and Ninfeias reservoir and abundance of species in the studied period. Scores abbreviations: the first letter indicates the ecosystem (B Barbosa lake, N Ninfeias reservoir) and the second letter indicates the month (April, May, June, October, November, December). Vectors: DO = Dissolved Oxygen; PM = Particulate matter; $\mathrm{pH}=\mathrm{pH}$; Secchi $=$ Transparency; Temp $=$ Water temperature; Cond $=$ Electrical conductivity. The squares indicate the species. The acronym of species names are shown in Table 1. 
component of CCA. The water temperature and transparency and $\mathrm{pH}$ were correlated positively with the rainy months, when high values of the variables were observed. The species $L$. friderici, $A$. lacustris, G. carapo, S. marginatus, A. fasciatus, S. insculpta and P. maculatus were associated to the rainy months. Conversely, $C$. modestus, $H$. littorale, $H$. bifasciatus, S. nasutus, S. borelli and G. sylvius were linked to suspended matter in water, which presented higher values in the dry period.

\section{Discussion}

The fish species richness found in the Barbosa lake during our studies corresponded to approximately $28.8 \%$ of the species with current recorded occurrence in the Paranapanema River-oxbow lake system at the Jurumirim Reservoir by Kurchevski (2012). After carrying out studies in lateral lakes and in the main channel of the Paranapanema River, Carvalho et al. (1998) recorded 21 species of fish in gillnet collections and pointed out that the greatest diversity was recorded in lakes compared to the principal channel of the river. However, the species richness reported for the Paranapanema River-marginal lake system in the Jurumirim Reservoir has now been expanded to 59 species (Kurchevski \& Carvalho, 2014). The highest abundance of specimens of the orders Characiformes and Siluriformes at Barbosa lake follows the pattern established by Lowe-McConnell (1999) for Neotropical freshwater environments, but the composition and richness vary in the different Brazilian watersheds (Agostinho et al., 2007a).

In the Ninfeias reservoir, the number of fish species found was very low for the Neotropical environment standards. However, in this particular case, we must consider that the small area of the lake and shallow depth may have acted as preponderant factors in the reduced occurrence and permanence of a higher number of fish species. Begon et al. (2007) established a direct relation between habitat area and depth and the number of species. The larger and deeper the area, the greater the species richness, which results from the environmental heterogeneity and the increase in the availability of resources in larger habitats (Ricklefs \& Relyea, 2016).

The ichthyofauna composition of the Barbosa lake, mainly consisting of small and medium-sized species, with a predominance of $P$. maculatus and A. altiparanae, may be associated to the massive presence of aquatic macrophytes that offer ideal shelter and foraging sites. Baginski et al. (2007) observed, in shallow environments of oxbow lakes, the best surface oxygenation conditions and the availability of both shelter and food, provided by the macrophytes shaping ecological refuges and which have additional advantages to the forms capable of exploring them better. Aquatic macrophytes increase the availability of shelters for foraging fish species and large juveniles, which reduces the number of deaths and, thus influences interspecific interactions (Savino \& Stein, 1982).

In the Ninfeias reservoir, the species composition consisted of only two species, and G. brasiliensis was the most abundant. This species predominantly occupies the calm regions and has daytime activity with visual orientation (Sabino \& Castro, 1990) and omnivorous (Sabino \& Castro, 1990; Moraes et al., 2004; Dias et al., 2005) or detritivorous feeding habits (Oliveira \& Bennemann, 2005). The second species, found in this reservoir is $H$. malabaricus, a predator with a diet mainly of fish and, occasionally, the consumption of other items of animal origin (Marçal-Simabuku \& Peret, 2002).

The highest abundance observed in the rainy season is due to a larger catch of fish in the connected lake. Studying marginal lakes, Baginski et al. (2007) reported that the abundance and richness of species vary over time. The same authors observed a gradual decrease of this community attributes from the beginning to the end of the dry season in the Pantanal region of Mato Grosso. Lowe-McConnell (1999) reported that the richness of a community is also affected by the conditions of the surrounding areas as the fish have great mobility. In the Amazon, Santos (1973) reported that the dynamism present in the fish allows them to enter the floodplain lakes soon after the water level rises when the supply of resources greatly improves, and they return to the rivers when the water level decreases. Súarez et al. (2004), studying factors determining the structure of fish communities in wetlands, showed that the species richness is negatively related to the isolation time and distance of the main river, but is positively related to the lagoon depth. These findings may be determinant in the low diversity found in the studied shallow reservoir.

In the Ninfeias reservoir, similar fish abundances were observed in the two periods of the year. Resource availability may initially affect the abundance of species (Ricklefs \& Relyea, 2016). Pellegrini \& Ferragut (2012) observed a seasonal variation of the algae community in the Ninfeias reservoir and pointed out that in the dry period there is more light and favors the development of periphyton. Other 
previous studies in the study area (PEFI) reported a significant development of the periphyton in the dry period (Vercellino \& Bicudo, 2006; Borduqui et al., 2008; Oliveira et al., 2010). The high nutrient availability, among other factors, was associated with the significant development of periphyton (Vercellino \& Bicudo, 2006).

The most abundant species in the connected lake (Pimelodus maculatus Lacepède, 1803) was also one of the most important among Siluriformes caught in the lakes of the region by Carvalho et al. (1998) with gill nets. The species is a medium-sized migrating Pimelodidae, widely distributed in the Upper Parana River basin, abundant in rivers and riverine areas with lotic stretches for breeding (Agostinho et al., 2003). Pough et al. (2012) reported that some fish species undertake seasonal migrations, going from place to place, from deep water to the surface, to spawn or to feed.

The community structure of the connected lake presented a slight seasonal variation in species composition and diversity index. The lower Shannon diversity and evenness observed in the rainy season, despite presenting a greater richness and a greater number of specimens caught, was mainly due to the dominance of the $P$. maculatus species. In tropical regions, communities are affected by seasonal changes due to the expansion or contraction of the lacustrine environments during the rainy or dry season (Castro et al., 2003). Carvalho et al. (2003) correlated the modulating hydrological forces (precipitation and fluviometric level) with the relative abundance of fish as a function of the seasonality of these variables in the ecoregion (lakes located at the mouth of the Paranapanema River into the Jurumirim Reservoir) and found that abundance is higher in the rainy season.

Despite the seasonal differences in the diversity found in the connected lake, most of the species were considered constant or accessories in the samplings. Shibatta et al. (2007) reported that morphological differences of fishes allow the differentiated use of food resources and physical space promoting the coexistence of different species (Agostinho et al., 2007a). In addition, the presence of aquatic macrophytes determines a structural complexity in the littoral region and, greater diversity and stability of the biotic communities (Agostinho et al., 2007b).

Our results showed that the limnological conditions were seasonally different among the lentic environments studied. Seasonality may have directly affected the variation of the richness and abundance of the fish species and the increase in favorable conditions for the different species to remain in these environments. In the rainy season, higher temperatures and a rise in the water level increased the area of macrophyte cover (Dr. R. Henry - personal communication) and the habitat structural complexity in the connected lake to the Paranapanema River. Aquatic macrophytes positively affect assemblies and promote biodiversity through a chain of mechanisms, related to increasing habitat complexity, resource availability and shelter, as well as influencing interspecific relationships (Thomaz \& Cunha, 2010). Cesar \& Henry (2017), comparing the benthic organisms between the river and lateral area, mentioned that the continued connectivity of the river with the lateral area during the year apparently promotes a homogeneity and a similarity between these biotic communities of both aquatic environments.

Physical and chemical data of the Barbosa lake suggest that the water presents a trend to neutrality, higher amount of suspend matter and lower values of electrical conductivity and dissolved oxygen than in Ninfeias reservoir.

The CCA expresses how much of the variance in one set of variables can be explained by the other (Legendre \& Legendre, 2012). In this study, the analysis was very effective in expressing the variation of abundance of the studied species as a function of fluctuations in the abiotic variables, indicating that $\mathrm{pH}$, water temperature and transparency influence in the catch of the species present in clear waters.

The species richness of Siluriformes in Barbosa lake was not very representative when compared to Characiformes. However, it is worth mentioning that P. maculatus had the greatest abundance in this environment in October, which in a way may have been determined by the increased turbidity. According to Rodríguez \& Lewis Junior (1997), the turbidity of the water favors the permanence of species with little visual acuity. During the dry season, the composition of the fish species was strongly associated with water turbidity in the Orinoco River floodplain lakes, which presented a high abundance of Siluriformes and Gymnotiformes (Pouilly \& Rodríguez, 2004). In Barbosa lake, during the rainy season, the temperature and the transparency of the water were higher and favored the occurrence of species of small Characiformes that are oriented visually. Pouilly \& Rodríguez (2004) observed that the abundance of Siluriformes and Gymnotiformes diminishes in more transparent 
waters whereas the abundance of Characiformes and Cichlids tends to increase in waters of that type.

In the Ninfeas Reservoir, greater water transparency and a lower amount of suspended material were observed. According to Pouilly \& Rodríguez (2004), Cichlids, a group of the species G. brasiliensis, predominant in this environment, are visually oriented and are more associated with water transparency.

Petry et al. (2003), studying fish assemblages in connected and disconnected lakes in the floodplain of the upper Paraná River, observed that the composition changes in these environments throughout the year and that the greatest species richness is found in the disconnected lakes. For the authors, opportunistic fish species, such as those found in our study that are characteristic of lacustrine environments, may be favoured by the predominant autogenic conditions in disconnected lakes. On the other hand, the dilution effect found in the connected ponds acts negatively on the richness. Our results showed that connectivity was an important determinant of fish diversity.

Thus, long-term spatial and temporal studies of the ichthyofauna, the trophic relationships of the species occurring in lacustrine environments, correlated with the abiotic variations, can generate important information in order to better explain the dynamics of these environments as fish populations in these places are very susceptible to climatic variations.

\section{Conclusion}

We conclude that fish diversity was higher in the lake connected to the Paranapanema River and lower in the shallow reservoir, due its low size and depth. The observed seasonal variation was more responsible for determining the species abundance patterns over time than for change of the richness in the lakes. The connected lake is an important environment for developing the fish species that form the basis of the food chain, mainly because it offers shelter and food. In this case, the aquatic macrophytes, found in the lakes, play an important role in the resident species as they increase the spatial heterogeneity. However, long-term studies on the fish ecology of the studied lakes would be critical in terms of understanding the role they play in the reproductive dynamics, diet and population structure of fish farms in each site.

\section{Acknowledgements}

The first author would like to thank the Federal University of Mato Grosso (UFMT) by granting a postdoctoral license and the Sáo Paulo State
University (UNESP/Botucatu) for the logistic support. The authors would also like to thank Dr. Cláudio de Oliveira for identifying the fish species, Dr. Danilo A. O. Naliato for making the map, Hamilton A. Rodrigues, Maria Carolina de Almeida Castilho, Joaquim N. da Costa and Lúcio M. de Oliveira for helping with the fieldwork.

\section{References}

AgOsTinHO, A.A., GOMES, L.C. and JÚlio JUNIOR, H.F. Relaçôes entre macrófitas aquáticas e fauna de peixes. In: S.M. THOMAS and L.M. BINI, eds. Ecologia e manejo de macrófitas aquáticas. Maringá: EDUEM, 2003, pp. 261-279.

AGOSTINHO, A.A., GOMES, L.C. and PELICICE, F.M. Ecologia e manejo de recursos pesqueiros em reservatórios do Brasil. Maringá: EDUEM, 2007a, $501 \mathrm{p}$.

AGOSTINHO, A.A., THOMAZ, S.M., GOMES, L.C. and BALTAR, S.L.S.M.A. Influence of the macrophyte Eichhornia azurea on fish assemblage of the Upper Paraná River floodplain (Brazil). Aquatic Ecology, 2007b, 41(4), 611-619. http://dx.doi. org/10.1007/s10452-007-9122-2.

AMERICAN PUBLIC HEALTH ASSOCIATION - APHA. Standard methods for the examination of waters and wastewaters. Washington: APHA/AWWA/ WPCF, 2005.

BAGINSKI, L.J., FLORENTINO, A.C., FERNANDES, I.M., PENHA, J.M.P. and MATEUS, L.A.F. The spatial and temporal dimension of fish diversity of the vegetated littoral zone of marginal lagoons of the Cuiabá river floodplain, Pantanal, Brazil. Biota Neotropica, 2007, 7(3), 233-238. http://dx.doi. org/10.1590/S1676-06032007000300025.

BEGON, M., TOWNSEND, C.R. and HARPER, J.L. Ecologia de indivíduos a ecossistemas. 4. ed. Porto Alegre: Artmed, 2007, 740 p.

BICUDO, C.E.M., CARMO, C.F., BICUDO, D.C., HENRY, R., PIÁO, A.C.S., SANTOS, C.M. and LOPES, M.R.M. Morfologia e morfometria de três reservatórios do PEFI. In: D.C. BICUDO, M.C. FORTI and C.E.M. BICUDO, eds. Parque Estadual das Fontes do Ipiranga: unidade de conservação ameaçada pela urbanização de São Paulo. São Paulo: Secretaria do Meio Ambiente do Estado de São Paulo, 2002, pp. 141-158.

BORDUQUI, M., FERRAGUT, C. and BICUDO, C.E.M. Chemical composition and taxonomic structure vertical and seasonal variation of periphyton community in a shallow hypereutrophic reservoir (Garças Reservoir, São Paulo, Brazil). Acta Limnologica Brasiliensia, 2008, 20(4), 381-392.

CARVALHO, E.D., CASTRO, R.J., SILVA, V.F.B. and VIDOTTO-MAGNONI, A.P. Estrutura das assembleias de peixes nas zonas de ecótono da represa 
de Jurumirim (Alto do rio Paranapanema, SP). In: R. HENRY, ed. Ecótonos nas interfaces dos ecossistemas aquáticos. São Carlos: RIMA, 2003, pp. 249-278.

CARVALHO, E.D., MARCUS, L.R., FORESTI, F. and SILVA, V.F.B. Fish assemblage attributes in a small oxbow lake (Upper Paraná River Basin, São Paulo State, Brazil): species composition, diversity and ontogenetic stage. Acta Limnologica Brasiliensia, 2005, 17(1), 45-56.

CARVALHO, E.D., SILVA, V.F.B., FUJIHARA, C.Y., HENRY, R. and FOREST, F. Diversity of fish species in the river Paranapanema - Jurumirim Reservoir transition region (São Paulo, Brazil). Italian Journal of Zoology, 1998, 65(1), 325-330. http://dx.doi. org/10.1080/11250009809386841.

CASTRO, R.J., FORESTI, F. and CARVALHO, E.D. Composição e abundância da ictiofauna na zona litorânea de um tributário, na zona de sua desembocadura no reservatório de Jurumirim, Estado de São Paulo, Brasil. Acta Scientiarum, 2003, 25(1), 63-70. http://dx.doi.org/10.4025/actascibiolsci. v25i1.2084.

CESAR, D.A.S. and HENRY, R. Is similar the distribution of Chironomidae (Diptera) and Oligochaeta (Annelida, Clitellata) in a river and a lateral fluvial area? Acta Limnologica Brasiliensia, 2017, 29(6), 1-14. http://dx.doi.org/10.1590/ s2179-975x1217.

DAJOZ, R. Ecologia geral. São Paulo: Vozes, 1972, 472 p.

DIAS, A.C.M.I., BRANCO, C.W.C. and LOPES, V.G. Estudo da dieta natural de peixes no reservatório de Ribeirão das Lajes, Rio de Janeiro, Brasil. Acta Scientiarum, 2005, 27(4), 355-364. http://dx.doi. org/10.4025/actascibiolsci.v27i4.1270.

ESCHMEYER, W.N. and FONG, J.D. Species by family/subfamily [online]. San Francisco: California Academy of Sciences, 2018 [viewed 18 Apr. 2018]. Available from: http://researcharchive.calacademy. org/research/ichthyology/catalog/SpeciesByFamily. asp

ESCHMEYER, W.N., FRICKE, R. and VAN DER LAAN, R. Catalog of fishes: genera, species, references [online]. San Francisco: California Academy of Sciences, 2018 [viewed 18 Apr. 2018]. Available from: http://researcharchive.calacademy.org/ research/ ichthyology/catalog/fishcatmain.asp

HENRY, R. Represa de Jurumirim: ecologia, modelagem e aspectos sociais. 1. ed. Ribeirão Preto: Holos, 2014, $435 \mathrm{p}$.

INSTITUTO NACIONAL DE METEOROLOGIA - INMET [online]. Brasília, 2018 [viewed 20 Mar. 2018]. Available from: www.inmet.gov.br

JUNK, W.J., BAYLEY, P.B. and SPARKS, R.E. The flood pulse concept in river-floodplain systems. In: D.P. DODGE, ed. Proceedings of the International Large River Symposium. Ottawa: Canadian Journal of
Fisheries and Aquatic Sciences, 1989, pp. 110-127. Special Publication, vol. 106.

KURCHEVSKI, G. and CARVALHO, E.D. Os peixes da represa de Jurumirim: revisão temporal de estudos independentes. In: R. HENRY, ed. Represa de Jurumirim: ecologia, modelagem e aspectos sociais. 1. ed. Ribeirão Preto: Holos, 2014, pp. 325-342.

KURCHEVSKI, G. As assembleias de peixes da represa de Jurumirim (alto rio Paranapanema): status atual e mudanças históricas [Dissertação de Mestrado]. Botucatu: Instituto de Biociências de Botucatu, Universidade Estadual Paulista, 2012, 122 p.

LEGENDRE, P. and LEGENDRE, L. Numerical ecology. 3. ed. Amsterdam: Elsevier Science, 2012, 990 p.

LOWE-MCCONNELL, R.H. Estudos ecológicos de comunidades de peixes tropicais. São Paulo: EDUSP, $1999,535 \mathrm{p}$.

LUZ, S.C.S., EL-DEIR, A.C.A., FRANÇA, E.J. and SEVERI, W. Fish assemblage structure in a marginal lake disconnected from the submedium São Francisco River, Pernambuco. Biota Neotropica, 2009, 9(3), 117-129. http://dx.doi.org/10.1590/ S1676-06032009000300011.

MAGURRAN, A.E. Measuring biological diversity. Oxford: Blackwell Science, 2004, 256 p.

MARÇAL-SIMABUKU, M.A. and PERET, A.C. Alimentação de peixes (Osteichthyes, Characiformes) em duas lagoas de uma planície de inundação brasileira da bacia do rio Paraná. Interciência [online], 2002, 27(6), 299-306 [viewed 18 Apr. 2018]. Available from: http://www.redalyc.org/articulo. oa?id=33906905

MCCUNE, B. and MEFFORD, M.J. Multivariate analysis of ecological data: PC-ORD version 5.0 . Gleneden Beach: MjM Software Desing, 2006, 40 p.

MESCHIATTI, A.J., ARCIFA, M.S. and FENERICHVERANI, N. Fish communities associated with macrophytes in Brazilian floodplain lakes. Environmental Biology of Fishes, 2000, 58(2), 133 143. http://dx.doi.org/10.1023/A:1007637631663.

MORAES, M.F.P.G., BARBOLA, I.F. and DUBOC, L.F. Feeding habits and morphometry of digestive tracts of Geophagus brasiliensis (osteichthyes, cichlidae), in a lagoon of high tibagi river, Paraná state, Brazil. Publicatio UEPG: Ciências Biológicas e da Saúde, 2004, 10(1), 37-45.

OLIVEIRA, D. and BENNEMANN, S.T. Ictiofauna, recursos alimentares e relaçóes com as interferências antrópicas em um riacho urbano no sul do brasil. Biota Neotropica, 2005, 5(1), 95-107. http://dx.doi. org/10.1590/S1676-06032005000100011.

OLIVEIRA, D.E., FERRAGUT, C. and BICUDO, D.C. Relationships between environmental factors, periphyton biomass and nutrient content in Garças Reservoir, a hypereutrophic tropical reservoir in southeastern Brazil. Lakes and Reservoirs: Research and 
Management, 2010, 15(2), 129-137. http://dx.doi. org/10.1111/j.1440-1770.2010.00428.x.

PELLEGRINI, B.G. and FERRAGUT, C. Variação sazonal e sucessional da comunidade de algas perifíticas em substrato natural em um reservatório mesotrófico tropical. Acta Botanica Brasílica, 2012, 26(4), 810-821. http://dx.doi.org/10.1590/S010233062012000400010.

PETrY, A.C., AGOSTINHO, A.A. and GOMES, L.C. Fish assemblages of tropical floodplain lagoons: exploring the role of connectivity in a dry year. Neotropical Ichthyology, 2003, 1(2), 111-119. http:// dx.doi.org/10.1590/S1679-62252003000200005.

POUGH, F.H., JANIS, C.M. and HEISER, J.B. Vertebrate life. 9th ed. Upper Saddle River: Pearson Prentice Hall, 2012, 720 p.

POUILLY, M. and RODRÍGUEZ, M.A. Determinism of fish assemblage structure in Neotropical floodplain lakes: influence of internal and landscape lake conditions. In: R.L. WELCOMME and T. PETR, eds. Proceedings of the Second International Symposium on the Management of the Large Rivers for Fisheries. Rome: Food and Agriculture Organization of the United Nations \& the Mekong River Commission, 2004, pp. 243-265.

RICKLEFS, R. and RELYEA, R. A economia da natureza. 7. ed. Rio de Janeiro: Guanabara Koogan, 2016, 606 p.

RODRÍGUEZ, M. and LEWIS JUNIOR, W.M. Structure of fish assemblages along environmental gradients in floodplain lakes of the Orinoco River. Ecological Monographs, 1997, 67(1), 109-128. http:// dx.doi.org/10.2307/2963507.

SABINO, J. and CASTRO, R.M.C. Alimentação, período de atividade e distribuição espacial dos peixes de um riacho da Floresta Atlântica (sudeste do Brasil). Revista Brasileira de Biologia, 1990, 50(1), 23-36.

SANTOS, U.M. Beobachtungen über Wasserbewegungen, chemische Schichtung und Fischwanderungen in Várzea-Seen am mittleren Solimóes (Amazonas). Oecologia, 1973, 13(3), 239-246. http://dx.doi. org/10.1007/BF00360514. PMid:28308580.
SAVINO, J.F. and STEIN, R.A. Predator-prey interactions between largemouth bass and bluegills as influenced by simulated, submersed vegetation. Transactions of the American Fisheries Society, 1982, 111(3), 255-266. http://dx.doi.org/10.1577/15488659(1982) 111<255:PIBLBA>2.0.CO;2.

SHIBATTA, O.A., GEALH, A.M. and BENNEMANN, S.T. Ichthyofauna from the middle and upper stretches of rio Tibagi basin, Paraná, Brazil. Biota Neotropica, 2007, 7(2), 125-134. http://dx.doi. org/10.1590/S1676-06032007000200014.

SILVA, C.V. and HENRY, R. Aquatic macroinvertebrates associated with Eichhornia azurea (Swartz) Kunth and relationships with abiotic factors in marginal lentic ecosystems (São Paulo, Brazil). Brazilian Journal of Biology = Revista Brasileira de Biologia, 2013, 73(1), 149-162. http://dx.doi.org/10.1590/S151969842013000100016. PMid:23644797.

SÚAREZ, Y.R., PETRERE-JÚNIOR, M. and CATELLA, A.C. Factors regulating diversity and abundance of fish communities in Pantanal lagoons, Brazil. Fisheries Management and Ecology, 2004, 11(1), 45-50. http://dx.doi.org/10.1111/j.13652400.2004.00347.x.

THOMAZ, S.M. and CUNHA, E.R. The role of macrophytes in habitat structuring in aquatic ecosystems: methods of measurement, causes and consequences on animal assemblages' composition and biodiversity. Acta Limnologica Brasiliensia, 2010, 22(2), 218-236. http://dx.doi.org/10.4322/ actalb.02202011.

VERCELLINO, I.S. and BICUDO, D.C. Sucessão da comunidade de algas perifíticas em reservatório oligotrófico tropical (São Paulo, Brasil): comparação entre período seco e chuvoso. Revista Brasileira de Botanica. Brazilian Journal of Botany, 2006, 29(3), 363-377. http://dx.doi.org/10.1590/S010084042006000300004.

ZAR, J.H. Biostatistical analysis. 5th ed. Upper Saddle River: Prentice Hall, 2010, 944 p.

Received: 13 December 2017 Accepted: 03 October 2018 